\title{
LAND ADMINISTRATION SYSTEMS DEVELOPMENT TRENDS - A CASE STUDY
}

\author{
Agnieszka Dawidowicz, PhD \\ Faculty of Geodesy and Land Management \\ University of Warmia and Mazury in Olsztyn \\ e-mail:agnieszka.dawidowicz@uwm.edu.pl \\ Winrich Voß, Prof., PhD \\ Leibniz University of Hannover, Germany \\ Geodetic Institute \\ Faculty of Civil Engineering and Geodetic Science \\ e-mail:voss@gih.uni-hannover.de
}

\section{Bernd Leonard, Engr.}

Head of Cadastral Office Hannover, Germany

Agency for Geoinformation and Land Development Lower Saxony-Regional Directorate Hannover

e-mail:bernd.leonard@lgln.niedersachsen.de

\begin{abstract}
Land management is aimed at generating optimal social, economic and environmental benefits while promoting sustainable development principles. An essential element of this process is the knowledge of the geospatial situation to support public decision-making at different levels: local, regional, national and global. Hence, there is a need for rapid access to complete and updated information about the physical characteristics of a property, rights, restrictions, responsibilities and interrelations. This information is provided by land administration systems (LAS). LAS are built and maintained by governments. The core of LAS is a multi-purpose cadastral system integrated with other spatial information systems and public registers.

In this paper, the authors present the functional architecture and the assumptions of land administration systems built in Poland and Germany. The analysis results show the specificity of the systems' design in relation to socio-economic conditions.
\end{abstract}

Keywords: land, real estate cadastre, land administration system, land management.

\section{JEL Classification: P51.}

Citation: Dawidowicz A., Voß W., Leonard B., (2013), “Land administration systems - development trends - a case study", Real Estate Management and Valuation, vol. 21, no. 2, pp. 83-92.

DOI: $10.2478 /$ remav-2013-0020.

\section{Introduction}

LAS are constructed on the basis of a cadastral reference system. Cadastres support the effective functioning of many countries but there are other solutions such as those found in the UK. The multipurpose real estate cadastre is priceless and extremely useful in land management and different business processes, which has been confirmed by numerous studies, such as: FIG (1995, 1999), HENSSEN (1995), GAŹDZICKI (1995), LARSSON (1996), BENNETT et al. (2007, 2010), ENEMARK (2004, 2005, 2010a, 2010b), WILLIAMSON et al. (2010).

The article concerns the development of land administration systems, the importance if which has 
grown in the recent years, especially in connection with the land management paradigm (WILLIAMSON et al. 2010). This phenomenon is also important where the development of information technology is concerned but most of all, it is essential for sustainable development which is not attainable without sound land administration (UN/FIG 1996).

In order to understand the nature of the problem the authors decided to define the fundamental terms used in the article, such as: land, land administration, cadastre and land management. As regards the term of "land" in modern administration, it should be understood as an area of the surface of the earth, together with the water, soil, rocks, minerals and hydrocarbons beneath or upon it and the air above it. It embraces all things which are related to a fixed area or point of the surface of the earth, including the areas covered by water, together with the sea (HENSSEN 1995).

There are many different definitions of a cadastre, the two most important and modern ones have been presented on the FIG (International Federation of Surveyors) forum (http://www.fig.net). One of them is the definition given by Professor Jo Henssen (1995) at the Delft seminar, which was the basis for his work on the Concept of Cadastre 2014 (FIG 1998). The definition of a cadastre by HENSSEN (1995) is appropriate for the existing situation, which is as follows: a cadastre is a methodically arranged public inventory of data concerning properties within a certain country or district, based on a survey of their boundaries. Such properties are systematically identified by means of some separate designation. The outlines of the property and the parcel identifier are normally shown on large-scale maps which, together with registers, may show the nature, size, value and legal rights associated with the parcel for each separate property. A cadastre provides an answer to the questions of where and how much.

The definition of Cadaster 2014 can be adapted to take into account public and traditional law aspects as well: Cadastre 2014 is a methodically arranged public inventory of data concerning all legal land objects in a certain country or district, based on a survey of their boundaries. Such legal land objects are systematically identified by means of some separate designation. They are defined either by private or public law. The outlines of the property as well as the identifier together with descriptive data may show the nature, size, value and legal rights or restrictions associated with each particular land object. In addition to this descriptive information defining the land objects, Cadastre 2014 contains the official records of rights to them. This inventory can provide answers to the questions of where, how much, who and how (FIG 1998).

Land administration was defined by UN-ECE (1996) as the processes of determining, recording and disseminating information about tenure value and the use of land when implementing land policies. By contrast, land management is the process by which the land resources are put into good effect (UNECE 1996). Land management is about policies, planning control, regulation, implementation, and development. In the words of ENEMARK (2003), it encompasses all those activities associated with the management of land as a resource that are required to achieve sustainable development. ENEMARK (2003) best explains the relationship between the identified concepts using the model presented in table 1.

The present article identifies the differences and similarities of land administration systems set up in Poland and Germany, to make it possible to determine the direction in which these systems will develop and evaluate the Polish system in relation to its German counterpart. The comparison of systems is very important, among others, for the following reasons:

- Germany is a highly economically developed country in Europe, which sets an example of good governance for Poland,

- the Republic of Poland directly borders the Federal Republic of Germany, which facilitates neighborly cooperation,

- Germany and Poland are members of the European Union and are obliged to adapt its common policies,

- on account of geographical location and the natural environment, the two countries have similar sociological relationships and environmental problems.

Table 1

Cadastre, Land Administration and Land Management - a conceptual approach

\begin{tabular}{|c|c|c|c|}
\hline Level & Objective & Context & Tool Box \\
\hline Overall Land & $\bullet$ Determining values and & $\bullet$ Social equity & $\bullet$ Constitutional Land \\
\hline
\end{tabular}




\begin{tabular}{|c|c|c|c|}
\hline Policy & $\begin{array}{l}\text { objectives in relation to land } \\
\text { and property as a legal, } \\
\text { economic and physical object. }\end{array}$ & $\begin{array}{l}\text { - Land tenure issues } \\
\text { - Land economics } \\
\text { - Land use } \\
\text { - Land and natural } \\
\text { resources }\end{array}$ & - Laws \\
\hline I Cadastre & $\begin{array}{l}\text { - Securing land rights } \\
\text { - Facilitating land markets } \\
\text { - Enabling land taxation } \\
\text { - Enabling land use control } \\
\text { - Basis for sound land } \\
\text { administration }\end{array}$ & $\begin{array}{l}\text { - Land parcel } \\
\text { identification } \\
\text { - Land registration } \\
\text { systems }\end{array}$ & $\begin{array}{l}\text { - Land recording laws } \\
\text { - Land registration } \\
\text { laws }\end{array}$ \\
\hline $\begin{array}{l}\text { II Land } \\
\text { Administration }\end{array}$ & $\begin{array}{l}\text { - Systems for administration } \\
\text { of: } \\
\text { - Land tenure } \\
\text { - Land value } \\
\text { - Land use } \\
\text { - Basis for sound land } \\
\text { management }\end{array}$ & $\begin{array}{l}\text { - Land Tenure } \\
\text { Systems } \\
\text { - Land value systems } \\
\text { - Land use control } \\
\text { systems } \\
\text { - Land development } \\
\text { systems }\end{array}$ & $\begin{array}{l}\text { - Institutional } \\
\text { frameworks } \\
\text { - Spatial data systems } \\
\text { and infrastructures }\end{array}$ \\
\hline $\begin{array}{l}\text { III Land } \\
\text { Management }\end{array}$ & $\begin{array}{l}\text { - Organise for management of } \\
\text { land and properties as an asset } \\
\text { and a scarce resource } \\
\text { - Basis for economic, social, } \\
\text { environmental sustainability }\end{array}$ & $\begin{array}{l}\text { - Natural resource } \\
\text { policies } \\
\text { - Land use policies } \\
\text { - Land data policies }\end{array}$ & $\begin{array}{l}\text { - Land use laws } \\
\text { - Policies and strategies } \\
\text { for: } \\
\text { - Land resource } \\
\text { management } \\
\text { - Institutional } \\
\text { infrastructures } \\
\text { - National spatial data } \\
\text { infrastructures }\end{array}$ \\
\hline
\end{tabular}

Source: ENEMARK 2003

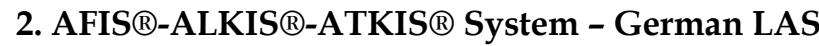

The Federal Government of Germany, together with the surveying institutes in the 16 states (länder), have worked on a NSDI (named: Geodateninfrastruktur Deutschland - GDI-DE®) over the last 15 years (GUNDELSWEILER et al. 2009). The cadastral data and topographical data sets of the surveying authorities are identified as basic elements in the German SDI (HAWERK, 2002). In the case of the AAA-Reference Model, a fundamental, technical and practical contribution for the GDI-DE is now available (SEIFERT, $2006 \mathrm{a}, \mathrm{b})$.

The AAA (AFIS®-ALKIS®-ATKIS®) Model, shown in the Fig. 1, includes the following three components $(\mathrm{AdV}, 2009)$ :

1) AFIS® - Official Fixed Point Information System

2) ALKIS® - Official Real Estate Cadastre Information System

3) ATKIS® - Official Topographic-Cartographic Information System

AAA is described within the "Documentation on the Modelling of Geoinformation of Official Surveying and mapping in Germany (GeoInfoDok)" (AdV 2009). There are positive aspects of country experience (MAGEL 2005):

- the cadastre becomes a part of the e-government and thus more important for business/industry (new clients!); it is no longer a matter of only securing property,

- the reputation of surveyor services provided in politics, as well as to the public, municipalities and industries is growing,

- more and quicker information is possible,

- a more comprehensive view of the environmental situation and (possible) land (use) conflicts,

- strengthening citizens' interest in public planning (e-participation through egovernance/services),

- creating new jobs for private experts,

- the more clients ask for ICT and LAS-Data the lower the costs will be. 


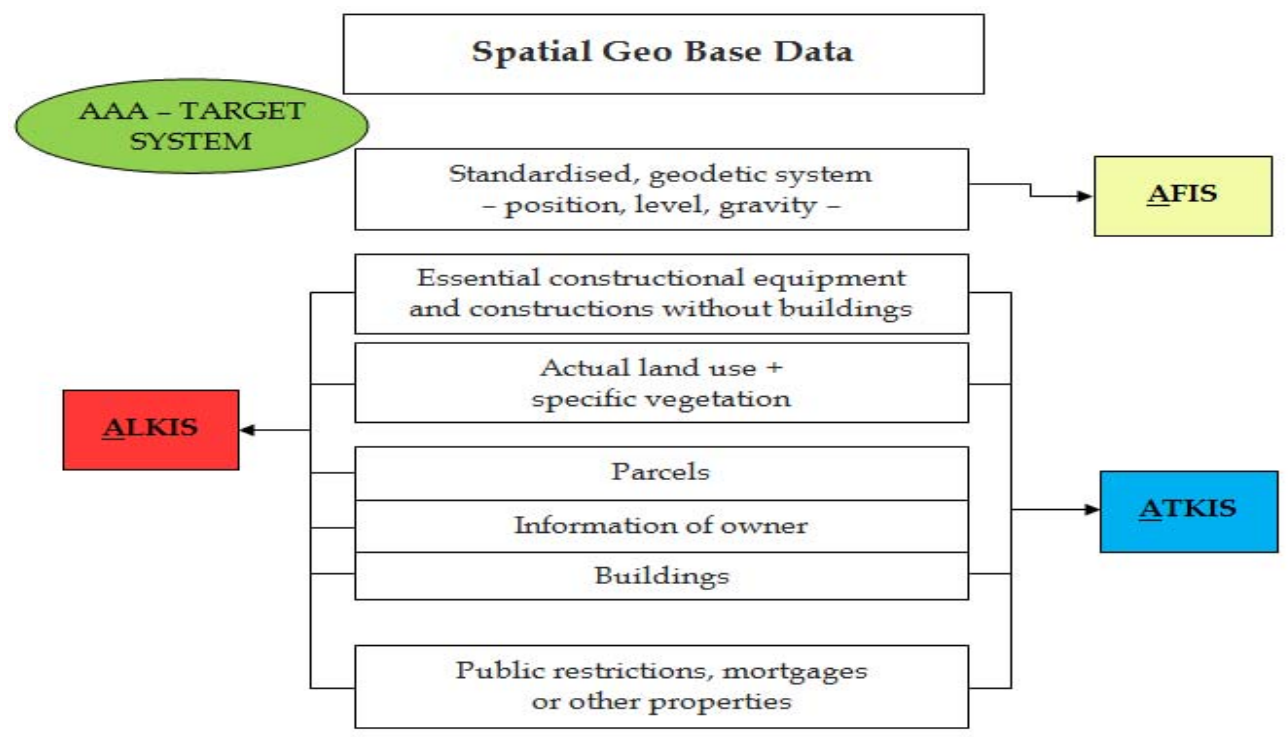

Fig. 1. Geo reference and Geo spatial data of the AAA model. Source: MAGEL 2005

\section{Integrated Real Estate Information System (ZSIN) - Polish LAS}

In the near future, the Polish LAS will function as an Integrated Real Estate Information System (zintegrowany system informacji o nieruchomościach - ZSIN). ZSIN will functionally integrate the Real Estate Cadastre, New Land and Mortgage Register (NKW), Tax system, Register of Economic Entities (REGON), Population Register (PESEL), National Register of Borders (PRG), National Register of Country Territorial Divisions (TERYT), Register of Agricultural Producers, Farms and Requests for payment, as well as other public records through the functional specification of the Integrating Electronic Platform (IPE) which will allow viewing and data transfer between a number of public registers (REGULATION OF 17 JANUARY 2013 ON ZSIN).

ZSIN will be based on the following functional assumptions shown in the diagram, which expand to a sub-module for analysis of the real estate market (Fig. 2):

1) there will be an exchange of data between the real estate cadastre and other public records in electronic form;

2) the software will automatically generate notifications of changes to the cadastre, the automatic generation of data updates;

3) access to cadastral data users will take place over the Internet;

4) procedures for data conversion and cadastral database updates will be implemented by a set of applications;

5) data integration will be carried out by an integrating Electronic Platform (IPE);

6) the data network will consist of LAN and WAN;

7) for the transformation of the source database of the real estate cadastre to a modern cadastral database, an application that integrates the descriptive part and mapping shall be installed. (DAWIDOWICZ, ŹRÓBEK 2012).

\section{LAS comparison}

The identification of differences and similarities of land administration systems set up in Poland and Germany in order to determine the direction in which the system will develop, requires the collection of comprehensive information on the general conditions under which these countries function.

The transparency of the criteria adopted and clarity of answers is essential to the study. That is why a tool table is the most suitable form of data aggregation. The comparative analysis of land administration systems was performed and has been presented in the tables 2 and 3 below. 


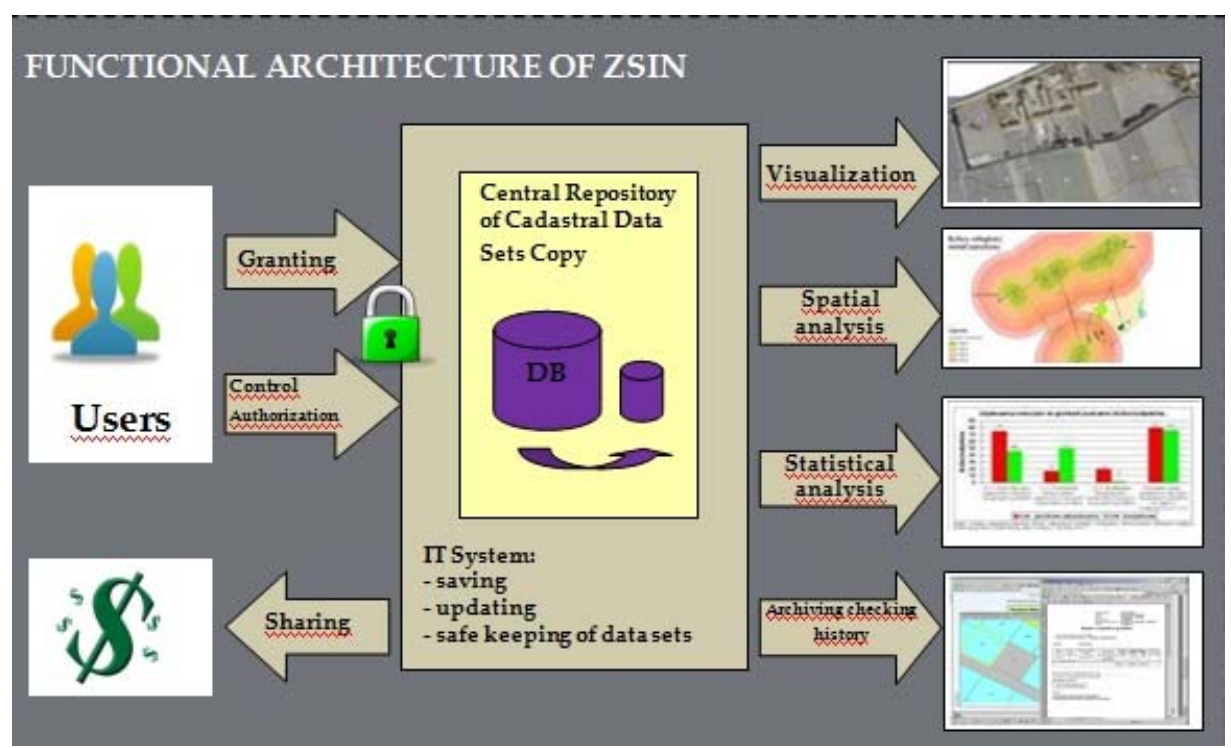

Fig. 2. Diagram of ZSIN functional architecture. Source: SOKOLIK, ZAJĄC, 2010

Table 2

Political and socio-economic states conditions

\begin{tabular}{|c|c|c|}
\hline \multirow{2}{*}{$\begin{array}{l}\text { Overview - State and } \\
\text { administrative context }\end{array}$} & \multicolumn{2}{|c|}{ Countries } \\
\hline & Germany & Poland \\
\hline $\begin{array}{l}\text { General location and } \\
\text { area }\end{array}$ & $\begin{array}{c}\text { Europe/ } \\
356854 \mathrm{sq} \mathrm{km} \\
\end{array}$ & Europe/ 312679 sq km \\
\hline Government & $\begin{array}{l}\text { Federal Republic of Germany (16 } \\
\text { states) }\end{array}$ & $\begin{array}{c}\text { Parliamentary Republic (Constitution } \\
\text { of } 2 \text { April 1997) }\end{array}$ \\
\hline $\begin{array}{l}\text { Division into sub- } \\
\text { units (federal state) }\end{array}$ & $\begin{array}{c}\text { Länder - federal states (16), district } \\
\text { level, municipalities }\end{array}$ & $\begin{array}{c}\text { Voivodship - higher level unit of } \\
\text { administrative division (16) } \\
\text { district level, municipalities }\end{array}$ \\
\hline $\begin{array}{c}\text { Population } 01 / 01 / 2012 \\
\text { /population density } \\
01 / 01 / 2011\end{array}$ & $\begin{array}{c}\text { 81,843,743 persons } \\
\text { 229.3 persons / sq km } \\
\text { (http://europa.eu/publications/statist } \\
\text { ics/index_pl.htm) } \\
\text { (EUROSTAT, 2012) }\end{array}$ & $\begin{array}{c}\text { 38,538,447 persons } \\
123 \text { persons / sq km (GUS 2012) }\end{array}$ \\
\hline $\begin{array}{l}\text { Gross domestic } \\
\text { product, current prices } \\
\text { 2011/ USD Billion } \\
\text { Dollars }\end{array}$ & $\begin{array}{c}3,577,031 \\
/ \text { 4th place in the world } \\
\text { (INTERNATIONAL MONETARY FUND, } \\
\text { 2011) }\end{array}$ & $\begin{array}{c}513821 \\
\text { /22nd place in the world } \\
\text { (INTERNATIONAL MONETARY FUND, } \\
\text { 2011) }\end{array}$ \\
\hline $\begin{array}{l}\text { Ministry / organization } \\
\text { supervising the real } \\
\text { estate information } \\
\text { system }\end{array}$ & $\begin{array}{l}\text { Depending on the states; Ministers } \\
\text { responsible for: } \\
\text { Interior; Finance; Rural affairs and } \\
\text { Consumer protection; Economy; } \\
\text { Environment, Construction and } \\
\text { Transport }\end{array}$ & $\begin{array}{l}\text { Ministers responsible for: Public } \\
\text { Administration, Internal Affairs, } \\
\text { Justice, Public Finances }\end{array}$ \\
\hline $\begin{array}{l}\text { Organization } \\
\text { responsible for } \\
\text { maintaining the } \\
\text { system at the country } \\
\text { level }\end{array}$ & $\begin{array}{l}\text { Arbeitsgemeinschaft der } \\
\text { Vermessungsverwaltungen der Länder } \\
\text { der Bundesrepublik Deutschland } \\
\text { (AdV) (Working Committee of the } \\
\text { Surveying Authorities of the States of } \\
\text { the Federal Republic of Germany) }\end{array}$ & Surveyor General of Poland \\
\hline $\begin{array}{l}\text { Organization } \\
\text { responsible for } \\
\text { maintaining the } \\
\text { system in the states / } \\
\text { federal states }\end{array}$ & $\begin{array}{c}\text { under the responsibility of the states, } \\
\text { cadastral offices organized in different } \\
\text { organizations at the state or communal } \\
\text { level }\end{array}$ & $\begin{array}{c}\text { Surveyor General of Poland in } \\
\text { cooperation with the starosts, } \\
\text { provincial governors and province } \\
\text { marshals }\end{array}$ \\
\hline
\end{tabular}

Source: own study. 
Table 3

Land Administration System - basic information

\begin{tabular}{|c|c|c|c|}
\hline \multirow{2}{*}{\multicolumn{2}{|c|}{ Land Administration System }} & \multicolumn{2}{|c|}{ Countries } \\
\hline & & Germany & $\begin{array}{l}\text { Poland } \\
\end{array}$ \\
\hline \multicolumn{2}{|c|}{ Name of system } & $\begin{array}{l}\text { The AFIS-ALKIS-ATKIS } \\
\text { reference model (AAA system) }\end{array}$ & $\begin{array}{c}\text { Zintegrowany System Informacji } \\
\text { o Nieruchomościach - ZSIN } \\
\text { (Integrated Real Estate } \\
\text { Information System) }\end{array}$ \\
\hline \multicolumn{2}{|c|}{ System concept } & $1980-1990$ & $1990-2000$ \\
\hline \multicolumn{2}{|c|}{ System startup } & $\begin{array}{l}\text { Running from } 2009 / 2010 \text { in } \\
\text { the individual federal states }\end{array}$ & $\begin{array}{l}\text { At the stage of modernizing } \\
\text { records, launched a pilot version } \\
\text { (Gdańsk, Katowice, Kraków, } \\
\text { Łódź, Poznań, Tychy); } \\
\text { incomplete, functional }\end{array}$ \\
\hline \multicolumn{2}{|c|}{ Data storage format } & $\begin{array}{c}\text { XML, } \\
\text { GML 3.0/ WFS/FE }\end{array}$ & $\begin{array}{c}\text { XML, } \\
\text { GML 3.0 } \\
\end{array}$ \\
\hline \multicolumn{2}{|c|}{ Legislation } & $\begin{array}{l}\text { INSPIRE Directive 2007, } \\
\text { cadastre is operated under } \\
\text { state law by cadastral } \\
\text { offices }\end{array}$ & $\begin{array}{l}\text { INSPIRE Directive 2007, Geodesy } \\
\text { and Cartography Act, Draft } \\
\text { Government Regulation on the } \\
\text { integrated real estate information } \\
\text { system }\end{array}$ \\
\hline \multicolumn{2}{|c|}{ Technical standards } & $\begin{array}{c}\text { ISO } 19100 \text { and OCG } \\
\text { Application Schema in UML }\end{array}$ & $\begin{array}{c}\text { ISO/TS } 21119100 \\
\text { Application Schema in UML }\end{array}$ \\
\hline \multirow{9}{*}{$\begin{array}{l}\text { Integrated } \\
\text { records }\end{array}$} & Real Estate Cadastre & + & + \\
\hline & $\begin{array}{l}\text { Land and Mortgage } \\
\text { Register }\end{array}$ & - & + \\
\hline & TAX system & - & + \\
\hline & $\begin{array}{l}\text { Topographic objects } \\
\text { database }\end{array}$ & + & + \\
\hline & $\begin{array}{c}\text { Cartographic } \\
\text { Information System }\end{array}$ & + & + \\
\hline & Population Register & - & + \\
\hline & $\begin{array}{c}\text { Register of Economic } \\
\text { Entities }\end{array}$ & - & + \\
\hline & $\begin{array}{c}\text { Register of } \\
\text { Agricultural } \\
\text { Producers, Farms and } \\
\text { Requests for payment }\end{array}$ & - & + \\
\hline & $\begin{array}{l}\text { Open to connect with } \\
\text { other systems }\end{array}$ & + & + \\
\hline
\end{tabular}

Source: own study

The core of LAS are cadastral systems. They have a direct impact on the shape of the LAS. Thus, it is very important to explore the Polish and German cadastre potential. This study has been performed for the descriptive and the graphic part of the cadastres (Table 4).

Table 4

Real estate cadastre - descriptive information

\begin{tabular}{|c|c|c|c|c|}
\hline \multirow{2}{*}{\multicolumn{3}{|c|}{$\begin{array}{c}\text { Content of the system - Descriptive } \\
\text { data }\end{array}$}} & \multicolumn{2}{|c|}{ Countries } \\
\hline & & & Germany & Poland \\
\hline \multirow{6}{*}{ 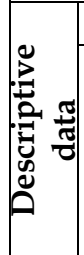 } & \multicolumn{2}{|c|}{ Basic unit } & property / parcel & parcel \\
\hline & \multirow{5}{*}{$\begin{array}{l}\text { Right to } \\
\text { the } \\
\text { property }\end{array}$} & Ownership & + & + \\
\hline & & Lease & - & + \\
\hline & & Servitudes & - & - \\
\hline & & Mortgage & - & - \\
\hline & & Other rights & Priority to purchase the & Perpetual use, sustainable \\
\hline
\end{tabular}




\begin{tabular}{|c|c|c|c|c|}
\hline & & & $\begin{array}{l}\text { property, ownership of the } \\
\text { building without the } \\
\text { ownership of land, housing } \\
\text { and property ownership of } \\
\text { land }\end{array}$ & $\begin{array}{c}\text { management, ownership of the } \\
\text { building without the ownership } \\
\text { of land, housing and property } \\
\text { ownership of land }\end{array}$ \\
\hline & \multirow{9}{*}{$\begin{array}{l}\text { Property } \\
\text { Details }\end{array}$} & Identifier & + & + \\
\hline & & $\begin{array}{c}\text { Information on } \\
\text { the entity }\end{array}$ & + & + \\
\hline & & Location & + & + \\
\hline & & Area & + & + \\
\hline & & Parcel No & + & + \\
\hline & & Type of land use & + & + \\
\hline & & Land quality class & + & + \\
\hline & & Land value & + & + \\
\hline & & $\begin{array}{l}\text { Additional } \\
\text { Information }\end{array}$ & $\begin{array}{l}\text { Date of the change to the } \\
\text { system, the number of } \\
\text { measurements, land } \\
\text { registration number, soil } \\
\text { contamination, monuments, } \\
\text { nature conservation data }\end{array}$ & $\begin{array}{l}\text { Cadastral map sheet number, } \\
\text { mortgage book number, history } \\
\text { of changes, link to the file name } \\
\text { of buildings and premises, links } \\
\text { to other registration records, inf. } \\
\text { on monuments }\end{array}$ \\
\hline \multirow{12}{*}{ 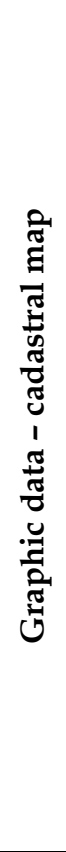 } & \multicolumn{2}{|c|}{ Basic unit } & parcel & parcel \\
\hline & \multirow{8}{*}{ Spatial data } & \begin{tabular}{|l|} 
Parcel No \\
\end{tabular} & + & + \\
\hline & & $\begin{array}{c}\text { Borders and } \\
\text { border points }\end{array}$ & + & + \\
\hline & & $\begin{array}{c}\text { Boundaries and } \\
\text { territorial } \\
\text { division } \\
\end{array}$ & + & + \\
\hline & & Buildings data & + & + \\
\hline & & Roads / streets & + & + \\
\hline & & $\begin{array}{c}\text { Land quality } \\
\text { class }\end{array}$ & + & + \\
\hline & & Land use & + & + \\
\hline & & Other data & $\begin{array}{c}\text { control network points, curbs, } \\
\text { bike lanes, trees, } \\
\text { embankments, retaining walls }\end{array}$ & $\begin{array}{l}\text { statistical area boundaries, } \\
\text { registered object names }\end{array}$ \\
\hline & \multirow{3}{*}{$\begin{array}{l}\text { Technical } \\
\text { conditions }\end{array}$} & Map format & digital & analog / digital \\
\hline & & Cartography & terrain measurements & $\begin{array}{c}\text { terrain measurements, } \\
\text { digitization, photogrammetric } \\
\text { images } \\
\end{array}$ \\
\hline & & Map scales & - & $1: 500$ to $1: 5000$ \\
\hline
\end{tabular}

Source: own study

The concept of the German Cadastral Information System - ALKIS was developed by the Working Committee of the Surveying Authorities of the States of the Federal Republic of Germany called AdV. This conceptual data model is completely object based and describes geographic and non-geographic features as well as their relations (associations). In order to describe this model in a standardized way, it has been based on the ISO standards in the field of geographic information (SEIFERT, 2002).

\section{Summary and conclusions}

In the last twenty years, in many economically developed countries, it has become a priority to construct efficient LAS. It has been repeatedly argued (WILLIAMSON et al. 2010, ENEMARK 2006, STEUDLER 2004, STEUDLER, WILLIAMSON 2005) that modern technology and integrated data sets for real estate have increased territorial cohesion in many countries and serve for a more complete implementation of the sustainable regional development policy. In addition, the clarification and harmonization of the real estate information system affects the economization of spatial planning and significantly enhances spatial order at the local level. LAS also affect the sealing of the local tax system 
- income of municipalities.

The AAA system functioning in Germany has already started to bring the aforementioned advantages, especially concerning the closer cooperation of geodetic and cartographic structures in independent länder and the harmonization of rules (MÜLLER, 2006, SEIFERT, 2006a,b). The completed research reflects the quality of the ZSIN system built in Poland when compared to the German AAA system.

Detailed knowledge of the LAS in Germany and Poland allowed for the following conclusions to be drawn:

1) German and Polish LAS concepts are developing in the same direction:

- the cadastral reference systems of these two countries are at the same level of detail in terms of the registered objects, although in Poland the process of modernizing and completing the cartographic part of the cadastre is still taking place and the descriptive database of buildings and premises is currently being realized,

- the common application schema provides for the recording and management of metadata and quality data in accordance with the ISO specifications (within the European framework guidelines for the construction of a geodata infrastructure in Europe, INSPIRE, the standard conformant modeling of geographic reference data, plays a significant role),

- the modeling is based on the results of ISO/TC 211 in the form of the 19100 series of standards at their current stage of processing in Poland, the database is in the conversion process,

- at the communication level, users are provided with object-structured or image-structured data, specially prepared information or analogue extracts that are able to hold the entire data content or extracts according to their content and area as well as management data for any number of time periods. Users' access to LAS data will take place over the Internet,

- both Germany and Poland decided to use the Unified Modelling Language (UML) for describing the application schema and the feature catalogue;

2) The differences that occur at the present stage result from the approach to the construction of the LAS. Despite the fact that Germany is a country that economically surpasses Poland sevenfold, it has begun to integrate data from the three spatial information systems and the German LAS continues to be open to expansion. Poland has designed a LAS based directly on multiple other public records, including the Land Register. This comprehensive approach will delay the process of starting ZSIN due to, for example, the need to harmonize data;

3) Assumptions of LAS building in Poland are at a high level but because of the economic situation, the development of the system should be carried out in stages;

4) Due to the many similarities between these two countries, Poland should seek cooperation with Germany in LAS development.

\section{Bibliography}

ADV, 2009, Documentation of Working Committee of the Surveying Authorities of the States of the Federal Republic of Germany on the Modelling of Geoinformation of Official Surveying and Mapping in Germany, Main Document Version 6.0.1. http://www.adv-online.de.

CONSTITUTION OF POLAND OF 2 April 1997 (Dz. U. z 2009 r, Nr 114, poz. 946).

DAWIDOWICZ A., ŹROBEK R., 2012, The evolving role of the cadastre in the land administration system in Poland, FIG/FAO International Seminar State Land Management in Transitional Countries: Issues and Ways Forward, Budapest, Hungary, Ministry of Rural Development, 20-21 September 2012.

COUNCIL OF MINISTERS REGULATION OF 17 JANUARY 2013 ON THE INTEGRATED REAL ESTATE INFORMATION SYSTEM (Journal of Laws of 2013, item. 249).

ENEMARK S., 2003, Underpinning Sustainable Land Administration Systems for Managing the Urban and Rural Environment, 2nd FIG Regional Conference Marrakech, Morocco, December 2-5.

ENEMARK S., 2004, Building Land Information Policies, Proceedings of Special Forum on Building Land Information Policies in the Americas, 26-27 October 2004, Aguascalientes, Mexico http://www.fig.net/pub/mexico/papers_eng/ts2_enemark_eng.pdf (5.12.2010).

ENEMARK S, 2006, Spatially Enabled Land Administration - Bridging the Gap, Presentation at the GSDI9 in Santiago, Chile, 3-10 November 2006. http://www.fig.net/council/enemark_papers /enemark_gsdi9_nov_2006_paper.pdf. 
Enemark S., Williamson I., Wallace J., 2005, Building Modern Land Administration Systems Developed Economies, pending publication, Journal of Spatial Science, Vol. 50(2): 51-68.

ENEMARK S., 2010a, From Cadastre to Land Governance: The role of land professionals and FIG, Annual World Bank Conference on Land Policy and Administration, 26-27 April 2010, Washington D.C.

ENEMARK S., 2010b, The Evolving Role of Cadastral Systems in Support of Good Land Governance, Open Symposium FIG 7 Commission, 9 September 2010, Karlovy Vary, Czech Republic.

EUROSTAT, 2012, General and regional yearbook 2012, Statistical books, ISBN 978-92-79-24940-2, http:/ / epp.eurostat.ec.europa.eu.

FIG, 1995, FIG Statement on the Cadastre, FIG publication No 11, FIG Office, Copenhagen, http://www.fig.net/commission7/reports/cadastre/statement_on_cadastre.html (5.12.2010).

FIG, 1998, Cadastre 2014. A vision for a future cadastral system. FIG publication No 15, http:/ / www.fig.net/cadastre2014/translation/c2014-english.pdf (accessed 22.02.2013).

FIG, 1999, Bathurst Declaration, http:/ / www.fig.net/pub/figpub/pub21/figpub21.htm (5.12.2010)

GAŹDZICKI J., 1995, Systemy katastralne, PPWK, Warszawa.

GEODESY AND CARTOGRAPHY ACT 1989 - Journal of Laws 2005, No. 240, item. 2027, as amended.

GUNDELSWEILER G., BARTOSCHEK T., DE SÁ, L. A. C. M., 2009, Development in the German cadastre, Bol. Ciênc. Geod., sec. Comunicações, Curitiba, v. 13, no 2, p.423-432, jul-dez.

GUS, 2012, Raport z wyników Narodowy Spis powszechny ludności i mieszkań 2011, Warszawa, http://www.stat.gov.pl/cps/rde/xbcr/gus/lud_raport_z_wynikow_NSP2011.pdf.

HAWERK W.,2002, Cadastre 2020 - New Trends in Germany's Cadastre?!, FIG Congress.

HENSSEN J., 1995, Basic Principles of the Main Cadastral Systems in the World, In Proceedings of the One Day Seminar held during the Annual Meeting of Commission 7, Cadastre and Rural Land Management, of the International Federation of Surveyors (FIG), May 16, Delft, The Netherlands.

INSPIRE Directive 2007/2/EC of the European Parliament and of the Council of 14 March 2007 establishing an Infrastructure for Spatial Information in the European Community (INSPIRE).

INTERNATIONAL MONETARY FUND, 2011, World Economic Outlook Database, April 2012: Nominal GDP list of countries. Data for the year 2011, http://www.imf.org/external/pubs/ft/weo/2012/01/ (accessed 10.02.2013).

LARSSON G., 1996, Land Registration and Cadastral Systems, Essex, UK, Addison Wesley Longman.

MAGEL H., 2005, Building Modern Land Administration Systems in Developed Economies - Aspects and Experiences from Germany, Expert Group Meeting "Incorporating Sustainable Objectives into ICT Enabled Land Administration Systems" 9 - 11 November 2005 in Melbourne.

MÜLLER H., 2006, Promoting Land Administration and Good Governance by SDI - The European Way 5th FIG Regional Conference Accra, Ghana, March 8-11.

NIK, 2006, Informacja o wynikach kontroli Zintegrowanego Systemu Katastralnego w latach 2000 - 2005 (I pótrocze), Warszawa, www.nik.gov.pl.

REgulation of RegionAl DEVElOPMENT AND CONSTRUCTION Minister - 29 March 2001 ON THE REAL ESTATE CADASTRE (Journal of Laws of 2001 No. 38, item. 454).

SEIFERT M., 2002, On the Use of ISO Standards in Cadastral Information Systems in Germany, FIG XXII International Congress, Washington, D.C. USA, April 19-26.

SEIFERT M., 2006a, AAA - the Contribution of the AdV in an Increasing European Spatial Data Infrastructure - The German Way, In: Shaping the Change, XXIII FIG Congress Munich, Germany, October 8-13, 2006, http:/ / www.fig.net/pub/fig2006/papers/ts59/ts59_03_seifert_0449.pdf.

SEIFERT M., 2006b, The AAA model as Contribution to the standardisation of the Geoinformation Systems in Germany, XXIII FIG Congress Munich, Germany, October 8-13.

SOKOLIK N., ZAJĄC B., 2010, Zintegrowany System Informacji o Nieruchomościach, Materiały szkoleniowe GUGiK dla pracowników administracji samorządowej, USTROŃ 20 - 22 października 2010 r. Poland.

STEUDLER D., 2004, A Framework for the Evaluation of Land Administration Systems, Submitted in total fulfilment of the requirements for the degree of Doctor of Philosophy, Department of Geomatics The University of Melbourne.

STEUDLER D., WILLIAMSON I.P., 2005, Evaluation of national land administration system in Switzerland. Case study based on a management model. Survey Review, 38(298), 317-330. http:/ / csdila.unimelb.edu.au/publication/journals/Evaluation \%20of \%20National\%20Land \%20A dministration \%20System \%20in\%20Switzerland.pdf. 
UN-ECE, 1996, Land Administration Guidelines, UNECE, Geneva, http://www.unece.org /env/hs/wpla/docs/guidelines/lag.html.

UN/FIG, 1996, The Bogor Declaration, United Nations Interregional Meeting of Experts on the Cadastre, Bogor Indonesia, March.

WilliamSON, I.P., ENEMARK, S., WALLACE, J. AND RAJABIFARD, A. 2010, Land Administration for Sustainable Development, ESRI Press Academic, Redlands, California. ISBN 978-1-58948-041-4. 497. 